\title{
Nicholas Draper
}

The Price of Emancipation: Slave-ownership, Compensation and British Society at the End of Slavery. Cambridge: Cambridge University Press, 2010. xiii + 401 pp. (Cloth Us\$99.00)

By posing the key question of what compensation meant to absentee British slave-owners, Nicholas Draper opens an intriguing investigation into an area largely neglected by historians. The answer may have direct relevance for contemporary political, social, and economic matters. In part because the focus of research over the last few decades has shifted either to the experiences of the enslaved or toward understanding slavery through a transatlantic and global lens, historians have missed the significance of the relatively small group of slave owners examined in The Price of Emancipation. Draper addresses this void by breaking down his overarching question into five parts: determining the ubiquity of slave ownership in metropolitan Britain; identifying slave owners and how they came to own slaves; clarifying how slave owners represented themselves and how they were perceived by others; examining how they managed to get compensation; and lastly, analyzing how Britain incorporated slave owners into narratives of nationhood.

Answering these questions will fuel the fire of contemporary debates about the complicity of past and present financial institutions and governments. Draper's close analysis of the Slave Compensation Commerce Commission records enables historians to better conceptualize "the extent and limits of Britain's complicity in slavery" (p. 7). He argues that not only did slavery benefit British elites in multiple ways, but the Commission records make possible identification of who benefitted from slavery's end through the process of compensation. His meticulous research demonstrates the value of feeding cold hard data into the often emotionally volatile debate over reparations.

The opening chapter notes that although abolitionists deftly managed, up through the 1820 s, to cast slavery as a national sin that harmed slaves, slave owners, and the country as a whole, slave owners were never completely ostracized in Britain. In part they avoided alienation by helping to fashion their own image as worthwhile members of society. Slave owners were not "systematically subject to social sanction" (p. 73), and during the apprenticeship period some abolitionists and slave owners, though by no means all, even worked together for common interests. More often, however, identities constructed during slavery defined interests during the age of emancipation and afterward, as absentee slave owners and their descendants tended to support policies that benefitted commercial interests at the expense of black laborers in the Caribbean and white workers in Britain.

(C) SCOTT HANCOCK, 2014 | DOI: 10.1163/22134360-08803017

This is an open access article distributed under the terms of the Creative Commons 
Draper uses individual examples effectively to contend that most absentee slave owners had multiple identities that stemmed from their various functions in British society. This contention is also consistent with the notion of slavery as a national sin: all were responsible on some level, so even though slave owners were pilloried, they were not expelled.

This was not the only ideological battle slave owners won. Perhaps even more critical was the question of whether owning slaves could, in the age of emancipation, be considered as a legitimate form of property ownership. Slave owners employed a variety of rhetorical and legal strategies that appealed to members of the upper class with no direct ties to slavery, such as warning that not validating men as property, and therefore not compensating slave owners for emancipated property, would seriously undermine the capability of slave owners to pay creditors.

The carefully thought out process of compensation, and the solid base of support for it among slave owners, non-slave owners, and a significant number of abolitionists, demonstrates that there was indeed a massively funded form of government reparations - but it was called compensation. Draper details the complex calculation that created a formula for compensation. Not everyone was happy with it, and some slave owners, such as the seventy-year old widow Dorothy Little from Bristol who inherited her husband's fourteen slaves in Jamaica, were cut out almost entirely. Little owned no land in Jamaica, and therefore stood to receive little or no compensation once her slaves were freed. Her primary income appears to have been derived from renting out her slaves; emancipation without compensation threatened to leave her destitute in the last years of her life.

Examples such as Little reveal the significant diversity among British slave owners. For instance, "resident" owners often overlapped into absentee ownership when they retired but maintained ownership for decades after returning to Britain. Absentee owners themselves varied significantly in scale and type of ownership; some were merchants who also owned slaves but aspired to become more like their well-to-do compatriots whose success derived almost solely from the profits of slave labor. Other small-scale owners such as Little similarly depended on slave labor but did so simply to maintain a far more modest lifestyle.

The Slave Compensation Commerce Commission's fairly rigid formula ultimately benefitted large-scale slave owners. They and the merchant owners scrambled to receive compensation, which helps to explain why Caribbean absentee owners received 51 to 55 percent of all the compensation awarded to British slave owners.

One ironic result of the age of emancipation was that large-scale slave owners increasingly embraced their identity as slave owners. While most had not 
initiated ownership (they more often were "reluctant planters" who had married into or inherited slave ownership), the financial liquidity that compensation offered motivated them to accept and even advocate for their status as slave owners in order to enhance or restore family finances. And even though they, along with merchant owners, were a minority among those with political influence in rural and urban areas, they were often strategically and disproportionately positioned among the elite in Britain's political and financial landscape. Ultimately the capital these owners accrued proved to be one of several significant sources of "funding for new industrial and infrastructure development, above all the railway boom" (p. 269). Unsurprisingly, though compensation helped dismantle slavery, it did not offer any financial reward to the formerly enslaved in the new industrializing political economy.

This book is a valuable contribution to emancipation studies, and most appropriate for upper-level undergraduate or graduate-level courses.

\section{Scott Hancock}

History and Africana Studies, Gettysburg College

Gettysburg PA 17325, U.S.A.

shancock@gettysburg.edu 